\title{
Protein-losing enteropathy caused by baffle obstruction after Mustard's operation
}

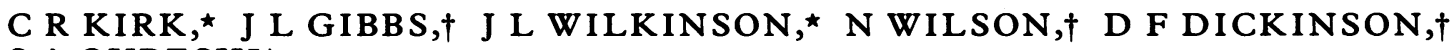 \\ $S$ A QURESHI* \\ From the ${ }^{\star}$ Department of Paediatric Cardiology, Royal Liverpool Children's Hospital, Liverpool; and the \\ $\dagger$ Department of Paediatric Cardiology, Killingbeck Hospital, Leeds
}

SUMMARY Three patients developed protein-losing enteropathy caused by intra-atrial obstruction of the systemic venous return after Mustard's operation. The enteropathy resolved in one case after reoperation and in the others after balloon dilatation of the stenosed caval pathways.

Protein-losing enteropathy may occur as a complication of Mustard's operation. Balloon dilatation of the obstructed baffle is an effective alternative to reoperation.

Obstruction of the systemic venous return is a recognised complication of Mustard's operation. Protein-losing enteropathy has been described in only two patients, ${ }^{12}$ however, both of whom had reoperation for relief of the enteropathy.

We describe three children who developed protein-losing enteropathy after combined obstruction of the superior and the inferior vena caval pathways after Mustard's operation. One was successfully treated by baffle reconstruction and the other two by balloon dilatation of the obstructed venous channels.

\section{Case reports}

\section{CASE 1}

A male infant with transposition of the great arteries had a balloon atrial septostomy at 24 hours of age. Three months later, Mustard's operation was performed using a Dacron patch as the intra-atrial baffle. The pulmonary venous atrium was also enlarged using dura mater. After operation mild periorbital oedema developed. Cardiac catheterisation and angiography showed almost total obstruction of the superior vena caval pathway. The oedema regressed spontaneously over three months.

Three years later he presented with recurrence of

Requests for reprints to Dr S A Qureshi, Department of Paediatric Cardiology, Royal Liverpool Children's Hospital, Myrtle Street, Liverpool L7 7DG.

Accepted for publication 9 September 1987 his facial oedema and was found to have hepatomegaly and ascites.

The serum protein concentration was $38 \mathrm{~g} / \mathrm{l}$, albu$\min 29 \mathrm{~g} / 1$, and globulin $9 \mathrm{~g} / 1$. The serum concentration of $\mathrm{IgG}$ was $1.19 \mathrm{~g} / \mathrm{l}$ (normal range $4 \cdot 24-10 \cdot 5$ $\mathrm{g} / \mathrm{l}$ ) but concentrations of IgA and IgM were normal. There was no proteinuria and the liver function tests were normal.

Studies with chromium-51 labelled albumin showed a faecal excretion of $20.2 \%$ of the intravenous dose over five days (normal value $<1.5 \%$ ).

A chest radiograph showed no cardiomegaly. The table shows the haemodynamic data. Angiography showed an occluded superior vena cava (fig la) and severe stenosis of the inferior vena cava (fig lb) with a dilated azygos vein. In addition, a left upper lobe pulmonary vein drained into the systemic venous atrium.

At reoperation, an intense endocardial reaction was found around the Dacron baffle suture line. A single orifice of the left pulmonary veins drained to the systemic venous atrium and the sites of obstruction were confirmed. The inferior caval pathway was partially obstructed by a shelf of tissue adjacent to the coronary sinus. A new intra-atrial baffle was constructed from calf pericardium.

He subsequently made a full recovery and six months later the total serum protein was $61 \mathrm{~g} / 1$ and albumin was $41 \mathrm{~g} / 1$.

\section{CASE 2}

A two week old boy with transposition of the great arteries underwent balloon atrial septostomy. At 


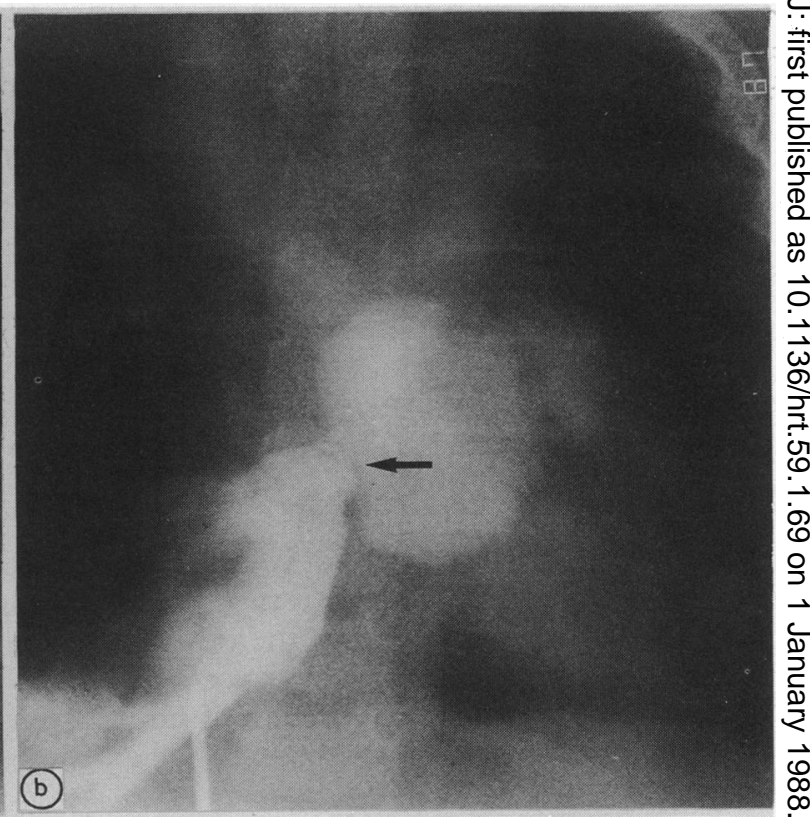

Fig 1 (a) Angiogram showing complete occlusion of superior caval pathway with a dilated azygos vein. (b) Angiogram showing severe stenosis (arrow) of inferior caval pathway.

seven months of age Mustard's operation was performed with a baffle constructed from autologous pericardium. His postoperative course was uncomplicated.

Five years later he presented with facial and peripheral oedema, hepatomegaly, and ascites. The total serum protein concentration was $32 \mathrm{~g} / \mathrm{l}$, albu$\min 15 \mathrm{~g} / \mathrm{l}$, and globulin $17 \mathrm{~g} / \mathrm{l}$. The serum concentration of $\operatorname{IgG}$ was $1.14 \mathrm{~g} / 1$ and the $\operatorname{IgA} 0.33 \mathrm{~g} / 1$ (normal range $0.5-2.5 \mathrm{~g} / \mathrm{l}$ ). The $\mathrm{IgM}$ and the liver function tests were normal and there was no proteinuria.

At cardiac catheterisation the mean pressures in the superior and inferior vena cavae were $15 \mathrm{~mm} \mathrm{Hg}$ and $3 \mathrm{~mm} \mathrm{Hg}$ higher than in the systemic venous atrium. Angiography showed occlusion of the superior vena caval pathway with drainage occurring

Table Haemodynamic data in case 1

\begin{tabular}{lll}
\hline Site & Saturation $(\%)$ & Pressure $(\mathbf{m m ~} \mathbf{H g})$ \\
\hline SVC & 64 & Mean 16 \\
IVC & 65 & Mean 15 \\
SVA & 74 & Mean 6 \\
LV & 74 & $36 / 5$ \\
MPA & 73 & $34 / 18$ \\
RV & 94 & $85 / 10$ \\
Ao & 97 & $88 / 48$ \\
\hline
\end{tabular}

SVC, superior vena cava; IVC, inferior vena cava; SVA, systemic venous atrium; $L V$, left ventricle; MPA, main pulmonary artery; RV, right ventricle; $A o$, aorta. $Q_{p} / Q_{0}=1 \cdot 5: 1$ (left to right shunt or systemic to pulmonary shunt). via a dilated azygos vein to the inferior vena cava. The inferior vena caval pathway was stenosed. The pulmonary venous return was normal.

The stenotic inferior vena caval pathway was dilated firstly with a $12 \mathrm{~mm}$ and then with a $20 \mathrm{~mm}$ Meditech balloon catheter. The oedema resolved within seven days and the serum concentrations of proteins returned to normal. Four months later his serum albumin was $38 \mathrm{~g} / 1$.

\section{CASE 3}

A neonate with transposition of the great arteries and a ventricular septal defect had a Blalock-Hanlon septectomy that was followed, at the age of one year, by Mustard's procedure. The ventricular septal defect was closed and an intra-atrial baffle was constructed from Dacron. He remained well for five $\mathrm{N}$ years but then developed complete heart block and $N$ required an epicardial pacemaker. At eleven years of $N$ age he returned with an eighteen month history of $\frac{\omega}{\sigma}$ progressive abdominal swelling. Examination showed generalised oedema, ascites, and hepatomegaly. The total serum protein concentration of was $39 \mathrm{~g} / \mathrm{l}$, albumin $19 \mathrm{~g} / \mathrm{l}$, IgG $3.6 \mathrm{~g} / \mathrm{l}$, IgA $0.8 \mathrm{~g} / 1$, and $\operatorname{IgM} 1.3 \mathrm{~g} / \mathrm{l}$. Liver function tests and urinalysis were normal.

Bilateral femoral venography showed thrombosis of the inferior vena cava below the renal veins. Cardiac catheterisation was performed by a percutaneous approach via the right subclavian vein. 

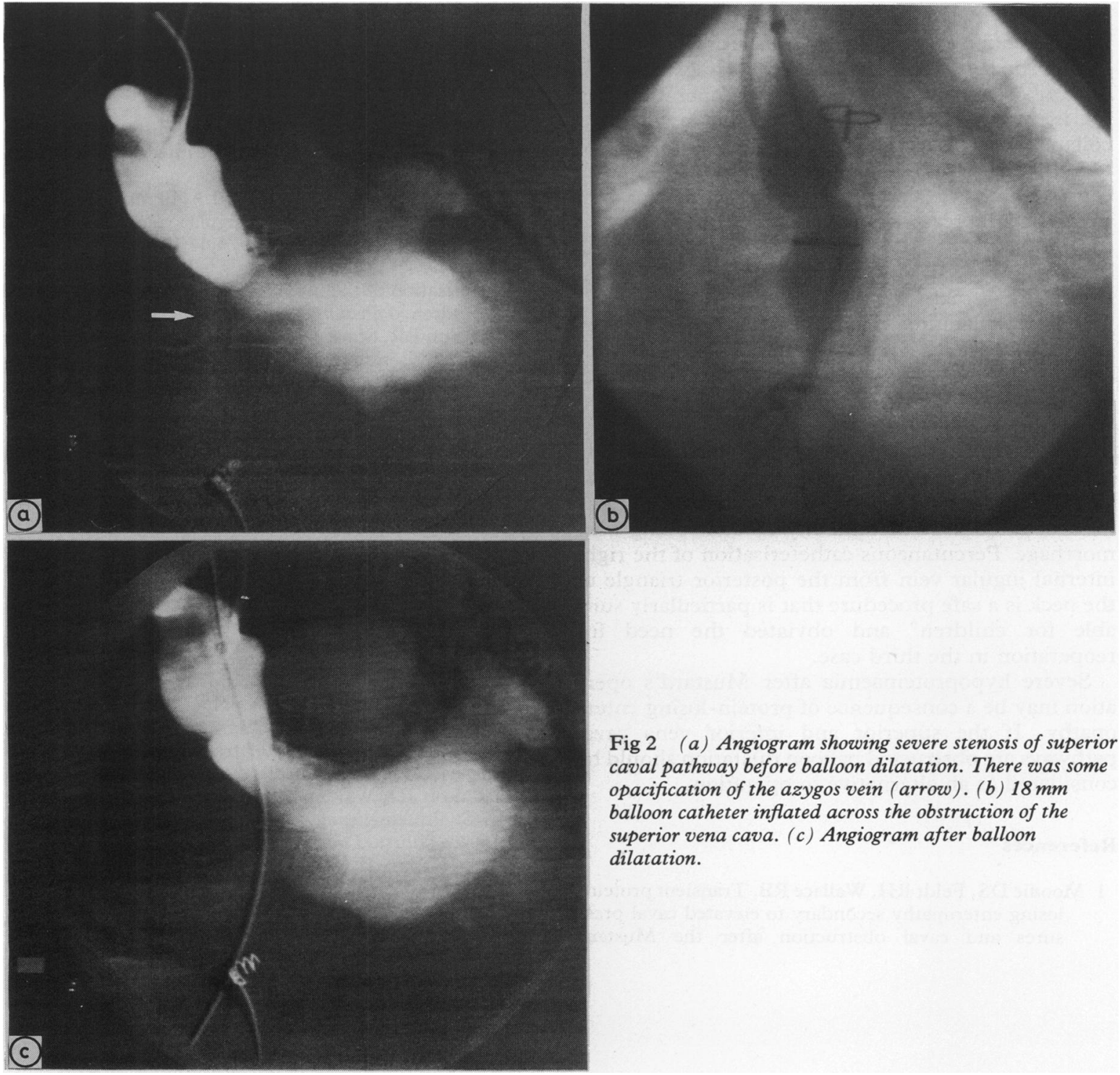

Fig 2 (a) Angiogram showing severe stenosis of superior caval pathway before balloon dilatation. There was some opacification of the azygos vein (arrow). (b) $18 \mathrm{~mm}$ balloon catheter inflated across the obstruction of the superior vena cava. (c) Angiogram after balloon dilatation.

The pressures in the superior and inferior vena cavae were $22 \mathrm{~mm} \mathrm{Hg}$ and $15 \mathrm{~mm} \mathrm{Hg}$ respectively and the left ventricular end diastolic pressure was 6 $\mathrm{mm} \mathrm{Hg}$. Angiography showed severe stenosis of superior (fig 2a) and inferior vena caval pathways. The right internal jugular vein was cannulated by an approach anterior to the sternocleidomastoid muscle ${ }^{34}$ but it proved impossible to advance a balloon catheter over a guide wire positioned in the vein. The internal jugular vein was recannulated by an approach posterior to the sternocleidomastoid muscle. ${ }^{56}$ An $18 \mathrm{~mm}$ Meditech balloon catheter was advanced through the systemic venous atrium and dilatation of the obstructed inferior limb was followed by dilatation of the superior limb (figs $2 b$ and c). The child had a considerable diuresis and there was a weight loss of $3.9 \mathrm{~kg}$. The concentration of serum proteins rose to $53 \mathrm{~g} / 1$ and albumin to $21 \mathrm{~g} / 1$.

\section{Discussion}

Protein-losing enteropathy may occur as a complication of various cardiac disorders ${ }^{7}$ and after cardiac surgery. ${ }^{89}$ It was first described after Mustard's operation in $1976^{1}$ and a further case was reported in $1977 .^{2}$ Obstruction of the vena caval pathway was 
the underlying cause of the enteropathy, and baffle reconstruction was required in each case.

The superior vena caval pathway is obstructed in $3-13 \%$ of patients after Mustard's operation, ${ }^{10} 11$ but is usually asymptomatic because of an adequate collateral circulation through the azygos venous system. The systemic venous pressure rises if there is coexistent obstruction of return in the inferior vena cava. This increase in pressure impairs drainage of the thoracic duct, the intestinal lymphatic vessels become engorged, and protein is lost from the gastrointestinal tract. ${ }^{12}$

Balloon dilatation via the femoral vein has been successful in relieving obstruction of the vena cava, ${ }^{13}$ and this technique was successful in our second case. In our third case, thrombosis of the inferior vena cava precluded this approach. In children it may be difficult or impossible to pass a balloon catheter with a large diameter from an antecubital vein and the subclavian vein approach is potentially hazardous because of difficulty in controlling haemorrhage. Percutaneous catheterisation of the right internal jugular vein from the posterior triangle of the neck is a safe procedure that is particularly suitable for children ${ }^{6}$ and obviated the need for reoperation in the third case.

Severe hypoproteinaemia after Mustard's operation may be a consequence of protein-losing enteropathy. If the superior and inferior vena caval pathways are obstructed balloon dilatation should be considered as an alternative to operation.

\section{References}

1 Moodie DS, Feldt RH, Wallace RB. Transient proteinlosing enteropathy secondary to elevated caval pressures and caval obstruction after the Mustard
Kirk, Gibbs, Wilkinson, Wilson, Dickinson, Qureshi procedure. J Thorac Cardiovasc Surg 1976;72: 379-82.

2 Krueger SK, Burney DW, Ferlic RM. Protein-losing enteropathy complicating the Mustard procedure. Surgery 1977;81:305-6.

3 English ICW, Frew RM, Pigott JF, Zaki M. Percutaneous catheterisation of the internal jugular vein. Anaesthesia 1969;24:521-31.

4 Prince SR, Sullivan RL, Hackel A. Percutaneous catheterisation of the internal jugular vein in infants and children. Anesthesiology 1976;44:170-4.

5 Hall DMB, Geefhuysen J. Percutaneous catheterisation of the internal jugular vein in infants and children. J Pediatr Surg 1977;12:719-22.

6 Chatrath RR, Stock JGL, Jones ODH. Internal jugular catheterisation in small children. The use of a posterior approach. Anaesthesia 1983;38:380-2.

7 Anonymous. Protein-losing gastroenteropathy in cardiac disease. $\mathrm{Br}$ Med J 1977;ii:1176.

8 Gleason WA, Roodman ST, Laks H. Protein-losing enteropathy and intestinal lymphangiectasia after superior vena cava-right pulmonary artery (Glenn) shunt. J Thorac Cardiovasc Surg 1979;77:843-6.

9 Hess J, Kruizinga K, Bijleveld CMA, Hardjowijono R, Eygelaar A. Protein-losing enteropathy after Fontan operation. J Thorac Cardiovasc Surg 1984;88:606-9.

10 Breckenridge IM, Oelert H, Stark J, Graham GR, Bonham-Carter RE, Waterston DJ. Mustard's operation for transposition of the great arteries: review of 200 cases. Lancet 1972;ii:1140-2.

11 Stark J, Silove ED, Taylor JFN, Graham GR, Kirklin $\mathrm{JW}$. Obstruction to systemic venous return following the Mustard operation for transposition of the great arteries. J Thorac Cardiovasc Surg 1974;68:742-9.

12 Davidson JD, Waldmann TA, Goodman DS, Gordon RS. Protein-losing gastroenteropathy in congestive heart-failure. Lancet 1961;i:899-902.

13 Lock JE, Bass JL, Castaneda-Zuniga W, Fuhrman BP, Rashkind WJ, Lucas RV. Dilation angioplasty of congenital or operative narrowings of venous channels. Circulation 1984;70:457-64. 